\title{
THE INTERFACE BETWEEN MARX AND BRUSSELS. EDITORIAL
}

\author{
Anu Printsmann ${ }^{1} \&$ Hannes Palang ${ }^{2}$
}

Received 10 July 2010; Accepted

\begin{abstract}
The editorial introduces papers mostly presented at the $22^{\text {nd }}$ session of the biennial Permanent European Conference for the Study of the Rural Landscape (PECSRL) in the sub-theme Interface between Marx and Brussels. The title of the Conference was European Rural Future: Landscape as an Interface and it was held from $4^{\text {th }}-9^{\text {th }}$ of September 2006 in Berlin and Hubertusstock, Brandenburg, Germany. The place and time were liminal as European Union (EU) accession included eight post-communist states on $1^{\text {st }}$ of May 2004. The papers that make up this twin special issue address the interface between the East/West and the past/future each uniquely.
\end{abstract}

Key words: Post-communist countries, transition, socio-economic formation, European Union (EU), rural landscapes

Teesid: Sissejuhatus tutvustab Euroopa Ruraalmaastike Uurimise Püsikonverentsi 22. Sessioonil toimunud allteema Piirpind Marxi ja Brüsseli vahel ettekannete põhjal valminud artikleid. Konverentsi üldteemaks oli Euroopa Ruraalne Tulevik: Maastik kui Kokkupuutepunkt ning see peeti 4.-9. septembrini 2006. a Berliinis ja Hubertusstockis, Brandenburgis, Saksamaal. Nii koht kui aeg olid sobivalt märgilised: 1. maist 2004. a kuuluvad kaheksa post-sotsialistlikku riiki Euroopa Liitu. Artiklid, mis moodustavad selle kaksik-erinumbri, lahkavad Ida-Lääne ja mineviku-tuleviku kokkupuutepindu igaüks isemoodi.

Võtmesõnad: Post-sotsialistlikud riigid, üleminek, sotsiaal-majanduslik formatsioon, Euroopa Liit, ruraalmaastikud

\section{Introduction}

The short period since the end of 1980s till 2004 witnessed the largest political changes in Europe since the Second World War. The Soviet Union collapsed; the former communist countries became members of the European Union (EU). The change from totalitarian regime into democratic civil society overwhelmed every imaginable and unimaginable aspect of public and private life. This transformation included free elections, politically unconstrained movement, housing and car

\footnotetext{
${ }^{1}$ Anu Printsmann, researcher, Centre for Landscape and Culture, Estonian Institute of Humanities, Tallinn University, Uus-Sadama 5, 10120 Tallinn, Estonia; e-mail: anu.printsmann@tlu.ee

2 Hannes Palang, Professor of Human Geography, Centre for Landscape and Culture, Estonian Institute of Humanities, Tallinn University, Uus-Sadama 5, 10120 Tallinn, Estonia; e-mail: hannes.palang@tlu.ee
} 
purchases, re-introduction of private ownership, dismantling of the collective farming, connecting to global market economy, and gradual application of European policies, the Common Agricultural Policy (CAP) amongst others. The fundamentals of societies' existence, underlying factors, modus operandi went through total alterations in a mere 15 years.

The radical path of changes had several highlights, of which no doubt the most emblematic is tearing down the Berlin Wall (9.11.1989) and German unification (3.10.1990). But these kind of ruptures do not just happen, they have an incubation phase (see Sewell 1996a), think for example about the Solidarity movement in Poland (since 1980), the Velvet Revolution (1989) and the peaceful split-up of Czechoslovakia (1993), break-up of Yugoslavia (since 1991), the formal dissolve of Soviet Union (1991). In Estonia and the Baltic States more generally the most publicised events like the Singing Revolution (1988) and the Baltic Human Chain of Freedom (23.08.1989 dedicated to $50^{\text {th }}$ anniversary of the Molotov-Ribbentrop Pact between the Soviet Union and Nazi Germany, which secret protocols divided Eastern Europe into spheres of influence and led to the occupation of the Baltics in 1940) were forestalled by the so-called Phosphorite War (19861988), formation of Estonian Heritage Society (12.12.1987) and active engagement of public intellectuals that pinned the importance of sustainable use of natural resources without immigrant workers (see the special issue From Phosphate Springs to Nord Stream: Contemporary Environmentalism in the Baltic States in the Journal of Baltic Studies 2009 edited by Galbreath) and valuing heritage supporting national identity, which always have had close ties between them (Printsmann et al. 2010, Rausing 2004, Smurr 2008, Young and Light 2001). Because of the influence of centuries-long presence of Baltic Germans, Herderian (stressing the influence of physical and historical circumstances upon human development, Heimat) and Ratzelian (the connections of the people with the soil by sweat and blood) ideas were well accepted. And all this transformation was done mainly without the help of computers, Internet or mobile phones.

These political and social events may have only had ephemeral effects onto landscapes, e.g. tearing down a $150 \mathrm{~km}$ wall makes no substantial change in larger physical environment but does so very much in every other realm. But we believe that these major political changes in society trigger a chain of events that translates into landscapes altering their appearance and perception.

\section{The paths and ways of landscape changes: from Marx to Brussels}

Cosgrove (1984), in his neo-Marxist stage, has described how each socio-economic formation tries to create its own landscape, erasing as much as possible from the previous one. A formation should be understood as a set of political, social, economical, ecological, cultural, aesthetical, symbolical, religious etc. conditions prevailing in a society (Palang et al. 2006). The transformation of 1990s is definitely a transition from one socio-economic formation to another by altering the ways in which land is shaped (see on land-scape/shape Olwig 1996, 2002).

Cosgrove's notion is not essentially different from much debated Sauer's (1925) understanding created to counterweight environmental determinism by stressing cultural factors - being thus regarded also as a cornerstone in cultural geography:

"The cultural landscape is fashioned from a natural landscape by a cultural group. Culture is the agent, the natural area is the medium, the cultural landscape is the result. Under the influence of a given culture, itself changing through time, the landscape undergoes development, passing through phases, and probably reaching ultimately the end of its cycle of development. With the introduction of a different - that is an alien culture, a rejuvenation of the cultural landscape sets in, or a new landscape is superimposed on remnants of an older one".

The wipe-out of the previous landscape can never be totally complete and even more so in very short period of time. Considering the spatial scale, the primary needs (e.g. growing food) and common sense, natural conditions set their limits to overall change. There are some notable exceptions that confirm the rule, e.g. attempts to reverse the rivers, grow corn in boreal climates, 
ameliorate bogs to fields, alongside ideological ones (figure 1). Thus, landscapes are pathdependent, having trajectories; otherwise we would not have heritage. It does not mean that landscapes are certainly evolutionary or teleological but people need the 'sense of direction' to be coping with the world. "The weak form of path dependency is simply the general idea that "what has happened at an earlier point in time will affect the possible outcomes of a sequence of events occurring at a later point in time" (Sewell 1996b: 262-263)" (Djelic and Quack 2007: 163). "While everyone agrees that history matters, no one agrees how history matters" (Schwartz 2004: 1, Zarina next issue) - what will be maintained and what remains. More importantly, what of these (natural or cultural) heritage monuments could be used for political ends? There exists a certain time lag in landscape changes (Maandi 2009), an inertia, making palimpsest landscapes possible (Vervloet 1984).

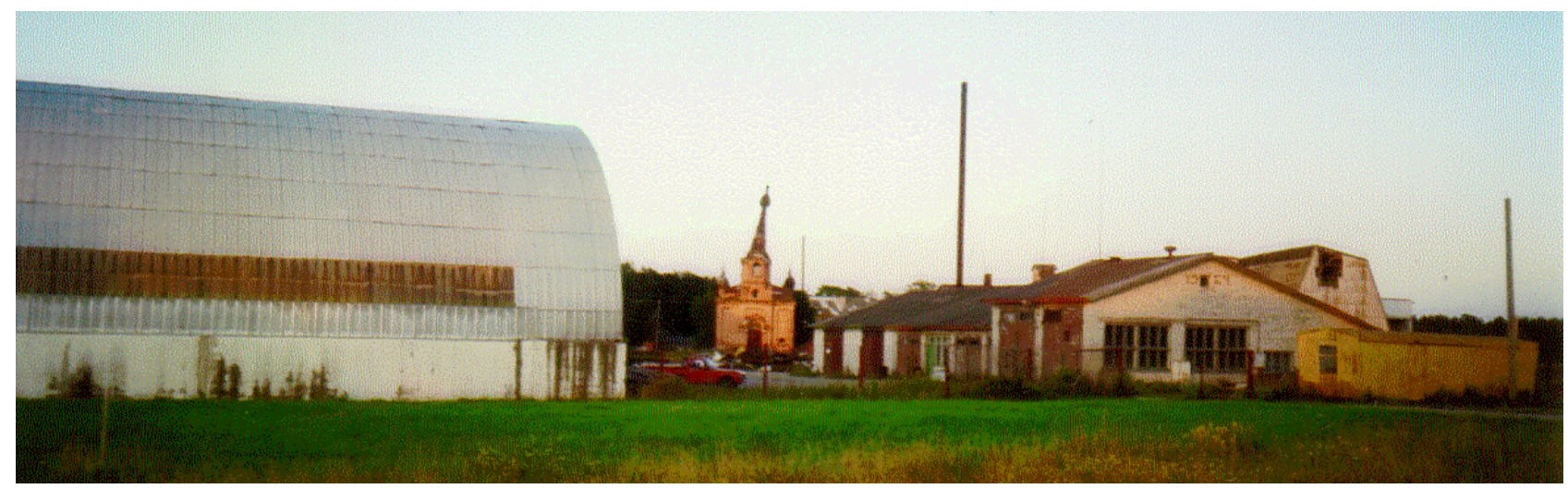

Fig 1. An example of ideological power play in a landscape: the village of Hullo, island of Vormsi, Estonia. This $93 \mathrm{~km}^{2}$ island was settled by approximately 2500 coastal Swedes. During the official Russification period of tsarist Russia (since 1870s) an Orthodox church was built in 1889. During Estonian interwar independence the congregation decreased. Most of the population fled to Sweden in 1943/44. After the war around 250 people from elsewhere settled on the island, who had no relation to the former landscape on the island. The soviets used the church as astore space although the land was not scarce (Palang et al. 1999, www.vormsi.ee). The storm of 2002 made the main dome of the architectural heritage to fall down. The restitution of lands to the per-War owners has also created a lot of conflicts (see Hedin 2005) (photo: H. Palang 2001).

The sequences of events (Sewell 1996a) influencing landscape come from at least two directions: 'up' and how they are decided to put into practice on spot, glocalisation in modern terms. In other words: landscapes are never produced locally in their entirety - theories, ideas, fashions, policies, methods, techniques and equipment generated elsewhere affect local life-style and by that also landscapes. At least the support or discouragement is coming from somewhere else. Not everything can be simply taken over; usually it needs some modifications and adjustments to be applicable. We find that the two biggest sources of influence on landscapes have been Marx and Brussels which ever ways they are harnessed.

These topics were tackled at the $22^{\text {nd }}$ session of the biennial Permanent European Conference for the Study of the Rural Landscape (PECSRL, perhaps the oldest landscape-focussed research network in Europe, see Helmfrid 2004, Palang et al. 2005 for more) titled European Rural Future: Landscape as an Interface held from $4^{\text {th }}-9^{\text {th }}$ of September 2006 in Berlin and Hubertusstock, Brandenburg, Germany. In addition to liminal time the places were also noteworthy. The hunting lodge of Hubertusstock was erected by King Frederick William IV of Prussia in 1849. In changing times, it served as a pleasure ground for men in power: the German Emperors from the House of Hohenzollern indulged in huntsmanship (Wilhelm II had his own train station built), as did the sidents Preof the Weimar Republic, Friedrich Ebert and Paul von Hindenburg. In 1944 Adolf Hitler 
gave the lodge to Obergruppenführer Hans Lammers and in 1973 it was rebuilt as a vacation home for General Secretary Erich Honecker ${ }^{3}$ (Wikipedia 2010a) - talking of path-dependency.

Despite the over 50 years of history PECSRL had been previously held only twice in Central and Eastern Europe: 1975 in Warsaw, Poland and 2002 in Tartu and Pühajärve, Estonia (www.pecsrl.org). In 2006 the post-conference excursion was organised in South-eastern Poland among which complexities (Skowronek et al. 2005) the most striking was the preserved hereditary strip-field system on loess ravines in Roztocze Region (Skowronek et al. 2006). The hereditary system is not sustainable and cannot be worked with machinery if the strips get narrower and narrower (figure 2). The plan was to use EU money to stop the system which has lasted for centuries creating beautiful landscapes. On the other hand, preserving the agricultural system the landscape will be simply eroded.

The sub-theme that papers in this twin issue originate was the Interface between Marx and Brussels. We were interested in comparing the first impacts of EU and CAP on 2004 accession countries, how different the policies of the past and present are, how different the outcomes have been because of the historical situatedness and implementation peculiarities, and what will the future bring. The papers are divided between two issues by addressing more economical and ecological concerns in the first number leaving those that fall into the scope of semiotics (Cosgrove 2003) to the next one.

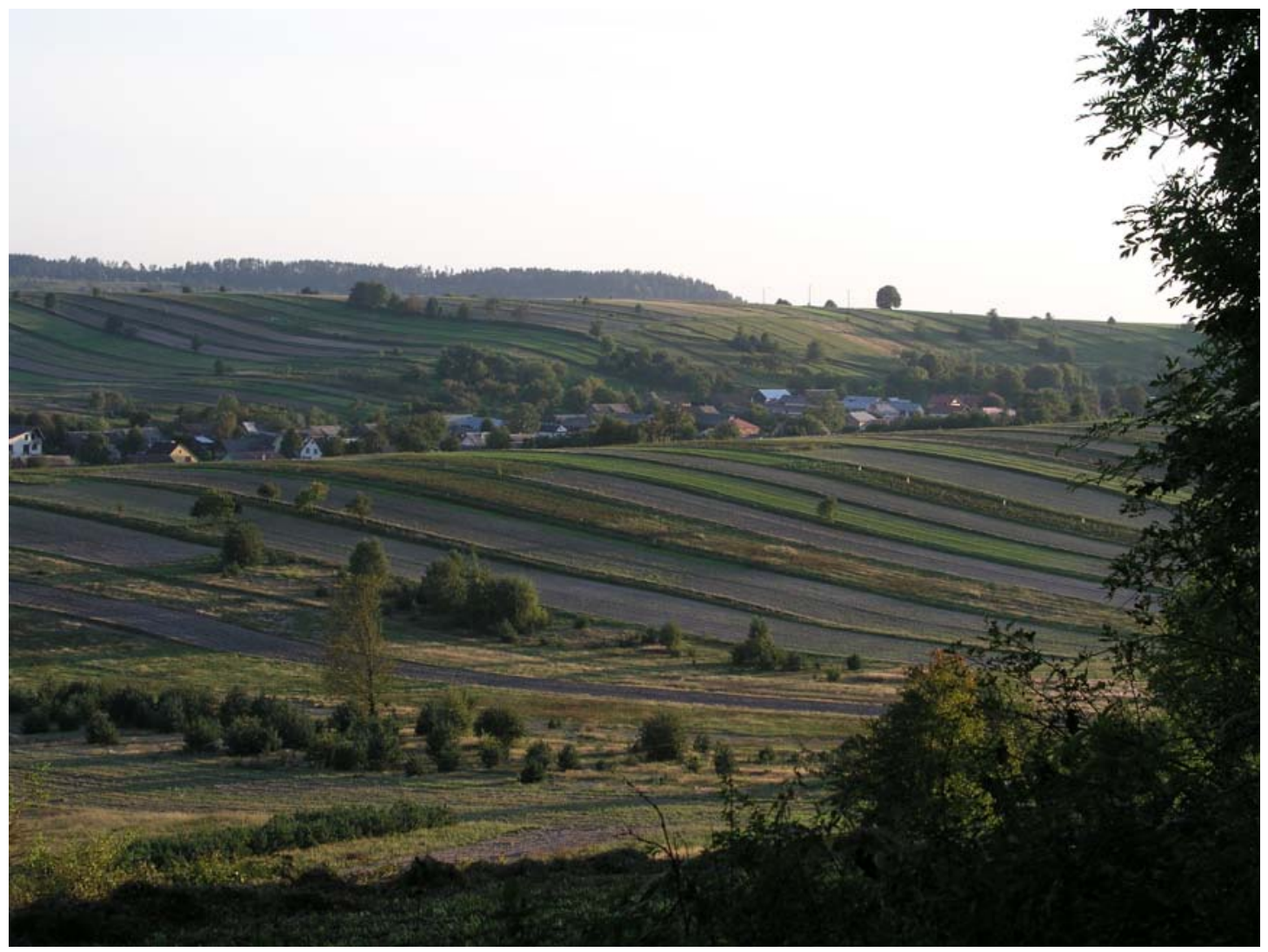

Fig 2. Hereditary erosion-prone strip field systems in Roztocze, Poland (photo: A. Printsmann 2006).

3 Wikipedia (2010a). Joachimsthal, Brandenburg http://en.wikipedia.org/wiki/Joachimsthal,_Brandenburg _ 10.07.2010. 


\section{Landscape as a set of interfaces}

Landscapes can be approached in several ways (e.g. Jones 1991, 1993, 2003, Olwig 1996, Widgren 2004); amongst all others there is one that handles landscape as a set of interfaces (Palang and Fry 2003). Interface can be understood as the place at which independent and often unrelated systems meet (e.g. natural sciences and social and cultural studies) and act on or communicate with each other, or the means by which interaction or communication is achieved (e.g. experts and lay persons on preservation and use). Here, it is proposed as a surface forming a common boundary of spaces, or phases, namely between different cultures (the East and the West), and amid the past, present and future. Each of the authors addresses these interfaces in their texts - whether knowingly or not - simultaneously trying to overcome that gap.

\section{The East and the West}

The development of landscapes in Western Europe has been steadier than in Central and Eastern Europe when considering socio-economic formations (Palang et al. 2006, Vos and Meekes 1999). If to look at Baltics they have witnessed four formations during the turmoil of the $20^{\text {th }}$ century, coinciding with rulers or state-orders: tsarist Russia, interwar independence, communism and democratic or postmodern landscapes. Interestingly enough, the implementation mechanisms of taking over seem to be alike (Palang next issue).

The social and cultural realms of the East and the West are and will always be incompatible, both in everyday and deeper levels. Whether the Victory Day is celebrated on May 8 or 9? The degree of repressions is unimaginable, ending in questions like: "Why didn't you call for police when they came to deport you and your family to Siberia?" Many of the behavioural patterns have long-haul influence on contemporary practices: e.g. perceiving the not punched ticket in public transport as admirable citizen disobedience; that illegal felling and burglaries were huge problem in 1990s; lifestories were not shared nor published and after the call for 'giving history back to the nation' and 'eliminating white spots of history' people still in 1997 before relinquishing their biographies asked: what if soviets should return (Hinrikus and Kõresaar 2004). Schizophrenic double-life found its way in cultural expressions - 'reading between the lines' - multi-layerness often missed today. There was no Christmas, as a religious holiday it was banned in Soviet Union but celebrated secretly. Queues for four or more hours to get anything, not to mention of deficit goods like bananas, coffee or ice cream 'when it reached the town'; a work-trip to Leningrad (now Saint Petersburg) or Moscow was a good chance to garner pantyhose or canned peas (the one and only brand 'Globus'). Strange hobbies like collecting the candy wrappers, plastic bags and freely taken-away ketchup and mustard packages as they were rare. Every proper household has some memorabilia of Moscow Olympic Games from the 1980.

Despite the fact that the discourse of the 'Other' prevails, the divide between the East and the West is gradually fading, from vocabulary, too, e.g. oppositional binaries like the old and new Member States of the EU and some things permeated even 'iron curtain', e.g. green movement or popular culture.

In this special issue we have been aspiring towards articles to be understandable and meaningful on both sides of 'iron curtain'. For that each of the papers was reviewed by one reviewer from the East and the other from the West. The 'situated knowledge' of geography matters (Garcia-Ramon 2003).

There are few who could boast the differences between the East and the West, one of them was the late Mark Blacksell from United Kingdom, the author of the first paper here. He combined human and physical geography, research and teaching, active engagement in society and executive positions with larger-than-life personality. He examined the geographical consequences of World War II, being a prolific author with over 100 publications, some of which were authoritative and ran through four editions (e.g. Blacksell and Williams 1994, Clout et al. 1985, 1989, 1992 and 
1996). Mark was one of the founding fathers of the sub-discipline of law and geography, investigating property restitution policies, legal access, recreation and conservation planning in rural, protected and wilderness landscapes, showing how development control decisions were changing the landscape influencing countryside; had some bearing on policy-makers and practitioners (Roberts et al. 2008).

What became apparent is a certain time-lag in approaches as social studies and humanities were suppressed in the East for about half of a century. With emancipation, free thought often too eagerly accepted Anglophone theories, 'copy-pasting' them onto post-communist situation, disregarding "... the fact that every situation is inevitably rooted in past situations" (Hägerstrand 1975 see Pred 1977: 208). The critique of such approaches has been scarce. Too often the past scholarly traditions were turned down completely, at least by younger researchers - making it a generational gap as well (Johnston 1978). Much of the East's scientists have been abound by understanding that gathering data is primary and generating theories secondary. Sociology of knowledge as a branch of historiography was also not acknowledged. Additionally, to come up with new theories on largely empty ground of social studies and humanities applicable to postcommunist situation in good English and accepted in the Western journals has been an effort. In order to get published one has to be distinguishable from the rest but not too much (Garcia-Ramon 2003, Johnston 1978). And Marx is popular in the West but less so in the East.

The linguistics may very well serve as an example here. We have adopted the Western view and talk of communism. In reality communism, as far as definition goes, never arrived; it was like a promising horizon - always on sight but unreachable. As other countries have adopted socialism that is not soviet, communism is used to separate these. Although 'socio-economic formation' was used by a Westener in the Marxist mood, reviewers needed explanation between 'formation' and transformation (transition). The language is never innocent: when talking of Central and Eastern Europe how many countries do we actually mean?

As Blacksell shows in this issue the discrepancies within one country may outdo international comparisons. Rural landscapes face polarisation into large agri-businesses and small-scale family enterprises (Blacksell, Nikodemus et al. this issue), whereas the subsistence farming on small holdings tends to be more related to the East (Abrahams 1994, Blacksell this issue, Herslund 2007, Nikodemus et al. this issue, Unwin 1997). When these former owners have had agricultural land returned to them, the overwhelming majority have not returned to farm the land, but rather sold it to add to the existing already large farms (Blacksell and Born 2002a and b). Marginalisation, land abandonment and overgrowth endangering appearance and biodiversity (Roose and Sepp this issue) being mainly the problems of 1990s are balanced out by intensification elsewhere (Nikodemus et al. this issue, Palang et al. 1998). And the EU activities from production subsidies to a more broadly conceived sustainable rural development strategy have had "a certain positive effect so far but not to the extent that was expected" (Nikodemus et al. this issue).

"One of the most important insights into this duality of intensification and marginalisation is that they are actually two sides of the same coin: investment and development in one area can inevitably lead to abandonment and decline in another. It follows that individual farm [or country] based solutions are unlikely to be successful in promoting a healthy industry and a sustainable rural environment. The emphasis needs to be on regional, publicly-led strategies, which have been arrived at democratically and which recognise the demands of all types of farm business" (Blacksell this issue).

The question that breaks many hearts is: how much of that idealised 1930s open landscape we need today to be kept open no matter of the costs in the globalised world market. All the landscapes in the East as well as in the West are affected by globalisation (Palang and Printsmann 2010), urbanisation, accessibility and the impact of calamities (Antrop 1997, 2004).

Another issue not completely tackled yet is: when will the post-communist transition be over? When did it start - in 1985, 1987, 1988, 1989? Does it exist at all? According to some objective measures, 
e.g. calculating averages of EU-27, some Central and Eastern European countries exceed the West but there will always be a range in figures, somebody has to be below the average. We believe that the answer lies in people (Maandi 2009) and their memories that tend to be subjective: bad times are always followed with the good ones (Alumäe et al. 2003). In the East we have had states that emerge and submerge, in the West each time a state appears, it is the new one, e.g. the republics of France and Germany - to stress the new.

\section{Past and present and future}

May be that the biggest problem when comparing the situations of 'before' and 'after' in Central and Eastern European countries is the availability of data. Maps were secret and statistical data when attainable not trustworthy: each 5-year plan in planned economy had to increase the production. As contemporary saying goes: 'there is a small lie, big lie and then there is statistics'. No doubt, in places due to industrialisation and mechanisation they succeeded but much of the progress took place on paper (Mander and Palang 1994, Peterson and Aunap 1998). Although, the Soviets admitted "... that they had falsified their topographic maps to confuse the enemy" (Harley 1989: 5) it has to be born in mind that all maps generalise and that land use categories may cover rather different phenomena (Vuorela et al. 2002).

However, it would be interesting to read about the re-structuring of the statistical offices of the countries when totalitarian regime was replaced by democratic one. As the statistics is the major player in proofing the change (see Nikodemus et al., Roose and Sepp this issue), although despite the efforts still hard to gain even on EU level based on common methodology (see Blacksell this issue). Yet now the reported data can be checked: the Big Brother is watching from satellites like in Foucaudian paranoia. Now the problem is that there is so much so detailed data that it becomes morally old before it is analysed.

The statistical indications and charts became almost bureaucratic obsession aspiring to EU.

Still, how otherwise progress of transition into civil society can be evaluated? Every policy applicable via programmes, projects, schemes etc. needs an assessment and feedback to be altered if necessary (see Nikodemus et al., Roose and Sepp this issue). The difficulty being that the policies themselves are undergoing radical transformations also partly as a response to enlargement (Blacksell this issue). Roose and Sepp (this issue) bring out how the monitoring sites for landscapes and biodiversity do not match. Like the Queen would say in Lewis Carrolls's Through the Looking-Glass, and What Alice Found There: “... it takes all the running you can do, to keep in the same place. If you want to get somewhere else, you must run at least twice as fast as that!"

To prove how time flies we can use abbreviations as an example. In preparatory stage for accession to the EU several enhancing and levelling programmes and projects were launched, e.g. PHARE (Poland and Hungary: Assistance for Restructuring their Economies; later covering ten Central and Eastern European countries) and SAPARD (Special Accession Programme for Agriculture and Rural Development). A decade ago they were as common as EU, CAP or UN now but today they need to be explained, especially in the West.

Still, the path-dependency can be seen at work: the gap left into legislation affects the landscape most severely, e.g. built-up lakeshores and accessibility problems in protected areas (Adamowicz next issue, Printsmann et al. 2010). After reprivatisation and land restitution the rich remained rich (communist egalitarianism was illusive) and poor became poorer, especially in rural areas (Born 2004, Nikodemus et al. this issue). Path-dependency also acts on individual level: younger farmers adapt more easily to demands of the new situation and are much more successful in gaining EU supports (Nikodemus et al. this issue). The societies used to top-down planning find it difficult to adapt to democratic, participatory planning, bottom-up approaches and missing local co-operation, e.g. in sustainable tourism management and every stakeholder (nature conservationists, tourism managers, local authorities and entrepreneurs) blames the other ones (Adamowicz next issue). It 
has been said that due to planned economy the level of entrepreneurship is low. The infrastructure does not meet contemporary demands (Adamowicz next issue). There are stories of foreign tourists returning from the forest on a bus trip with confusion - they did not find the toilets - but there supposed to be no toilets.

The problem with the past here is that since landscapes should and could be interpreted in their right historical context (Jones 1991) - with or without toilets -, we might be increasingly unable to understand the communist landscapes - a time barrier has been created between us and the communist landscape (Palang next issue, Palang et al. 2006).

As the present-day landscape consists of the outcomes of decision made in the past, the decisions made today affect its future. What worries us is the lack of long-term strategies and plans of all levels (Adamowicz next issue, Blacksell this issue), including scenario studies (see Alumäe et al forthcoming). The time for over-optimistic prognoses seems to be over. Twenty years ago every village and municipality wrote to their development plan that they possess tourism potential - as there has never been any tourist around. On the other hand, many of the protected areas are meant to be visited but not in the amounts of exceeding carrying capacity - the eternal conservation paradox. Policies influencing European countryside are directed with maximum 7-year plans. These largely standardised policies ape in a rather perverse way "the attempted uniformity of collectivisation in the former communist controlled parts of the continent, though from a very different political and economic starting point (Gray 2000)" (Blacksell this issue). On the other hand perhaps this 'shortsightedness' is an advantage considering the recent economic recession, situations need quick re-adjustments to be able to respond to changes in globalised markets, e.g. pandemics.

Yet it would be ultimate simplification to say that landscapes in Eastern Bloc or in smaller region have developed similarly. Additionally, even the local practices may be remembered differently: the grand historical narrative shatters when studied by complimentary methods (Palang, next issue, Printsmann next issue).

The society as a whole has to come to terms with its history - multiple pasts in the present - in order to adjust with ever-speeding changes in the future (Antrop 1998, 2000, 2005, Blacksell this issue, Palang et al. 2005). Some deny the past, some present; some adapt quicker, others feel nostalgic. The term nostalgia means literally 'ache for returning home', homesickness; regarded as medical condition in the Early Modern period especially among Swiss mercenaries ${ }^{4}$. Rumour has it that it started to spread in Russian army as well but stopped when it was treated with execution by firing squad. Nowadays, nostalgia stands for general interest in past eras, describing a yearning for the past, often in idealised form. But the future will come anyhow.

\section{Conclusions}

Inevitably the interface between the East and the West is the same with the past and present but hopefully in the future, it will be merely east and west (see Gregory 2001, 2009, Said 1978, Sheppard and Nagar 2004), especially if we, in the East, disregard 'the East and the rest' way of thinking (see the special issue on Regional Perspective: Transitional Landscapes in Eastern Asia in Landscape Research edited by M. Roe).

\footnotetext{
${ }^{4}$ Wikipedia (2010b). Nostalgia http://en.wikipedia.org/wiki/Nostalgia - 11.07.2010.
} 
References

[1] Abrahams, R. (1994). The regeneration of family farming in Estonia. Sociologia Ruralis 34 (4), 354-368.

[2] Alumäe, H., Printsmann, A. \& Palang, H. (2003). Cultural and historical values in landscape planning: locals' perception. In: Palang, H. \& Fry, G. (eds.) Landscape Interfaces. Cultural Heritage in Changing Landscapes (pp. 125-145). Series: Décamps, H., B. Tress \& G. Tess (eds.) Landscape Series Volume I. Dordrecht: Kluwer Academic Publishers,.

[3] Alumäe, H., Külvik, M. Palang H.: Futures revisited: using scenarios in illustrating landscape changes, European Countryside (in print)

[4] Antrop, M. (1997). The concept of traditional landscapes as a base for landscape evaluation and planning. The example of Flanders Region. Landscape and Urban Planning 38 (1-2), 105-117.

[5] Antrop, M. (1998). Landscape change: plan or chaos? Landscape and Urban Planning 41 (3-4), 155-161.

[6] Antrop, M. (2000). Background concepts for integrated landscape analysis. Agriculture, Ecosystems \& Environment 77 (1-2), 17-28.

[7] Antrop, M. (2004). Landscape change and the urbanization process in Europe. Landscape and Urban Planning 67 (1-4), 9-26.

[8] Antrop, M. (2005). Why landscapes of the past are important for the future. Landscape and Urban Planning 70 (1-2), 21-34.

[9] Blacksell, M. \& Born, K.M. (2002a). Private property restitution: the geographical consequences of official government policies in Central and Eastern Europe. Geographical Journal 168,178190.

[10] Blacksell, M. \& Born, K.M. (2002b). Rural property restitution in Germany's New Bundesländer: the case of Bergholz. Journal of Rural Studies 18, 325-338.

[11] Blacksell, M. \& Williams, A.M. (1994). The European Challenge: Geography and Development in the European Community. Oxford: Oxford University Press.

[12] Born, K.M. (2004). The dynamics of property rights in post-communist East Germany. In: Palang, H., Sooväli, H., Antrop, M. \& Setten, G. (eds.) European Rural Landscapes: Permanence, Persistence and Change in the Globalising Environment (pp. 315-332). Dodrecht: Kluwer Academic Publishers,.

[13] Carroll, L. (1871). Through the Looking-Glass, and What Alice Found There. London: Macmillan.

[14] Clout, H., Blacksell, M., King, R. \& Pinder, D. (1985). Western Europe: Geographical Perspectives. London: Longman.

[15] Cosgrove, D.E. (1984). Social Formation and Symbolic Landscape. Madison: University of Wisconsin Press.

[16] Cosgrove, D.E. (2003). Landscape: ecology and semiosis. In: Palang, H. \& Fry, G. (eds.) Landscape Interfaces. Cultural Heritage in Changing Landscapes (pp. 15-21). Series: Décamps, H., Tress, B. \& Tess, G. (eds.) Landscape Series Volume I. Dordrecht: Kluwer Academic Publishers.

[17] Djelic, M.L. \& Quack, S. (2007). Overcoming path dependency: path generation in open systems. Theory and Society 36 (2), 161-186.

[18] Galbreath, D.J. (ed.) (2009). Special issue From Phosphate Springs to Nord Stream: 
Contemporary Environmentalism in the Baltic States. Journal of Baltic Studies 40 (3).

[19] Garcia-Ramon, M.-D. (2003). Globalization and international geography: the questions of languages and scholarly traditions. Progress in Human Geography 27 (1), 1-5.

[20] Gray, J. (2000). The common agricultural policy and the reinvention of the rural in the European community. Sociologia Ruralis 40(1), 30-52. DOI: 10.1111/1467-9523.00130

[21] Gregory, D. (2001). Cultures of travel and spatial formations of knowledge. Erdkunde 54 (4), 297-319.

[22] Gregory, D. (2009). Regional geography. In: Gregory, D., R. Johnston, G. Pratt, M.J. Watts and S. Whatmore (eds.) The Dictionary of Human Geography, $5^{\text {th }}$ ed. Chichester: Wiley-Blackwell.

[23] Harley, J.B. (1989). Deconstructing the map. Cartographica 26 (2), 1-20.

[24] Hedin, S. (2005). Land restitution in the former Swedish settlement areas in Estonia consequences for land ownership, land use and landscape. Landscape and Urban Planning 70 (1-2): 35-44.

[25] Helmfrid, S. (2004). The permanent conference and the study of the rural landscape. In: Palang, H., Sooväli, H., Antrop, M. \& Setten, G. (eds.) European Rural Landscapes: Persistence and Change in a Globalising Environment (pp. 467-482). Dordrecht: Kluwer Academic Publishers.

[26] Herslund, L. (2007). Rural diversification in the Baltic countryside: a local perspective. GeoJournal 70, 47-59.

[27] Hinrikus, R. \& Kõresaar, E. (2004). A brief overview of life history collection and research in Estonia. In: Kirss, T., Kõresaar, E. \& Lauristin, M. (eds.) She Who Remembers, Survives. Interpreting Estonian Women's Post-Soviet Life Stories (pp. 19-34). Tartu: Tartu University Press

[28] Hägerstrand, T. (1975). Space, time and human conditions. In: Karlqvist, A., Lundquist, L. \& Snickars, F. (eds.) Dynamic Allocation of Urban Space. Lexington: Saxon House Lexington Books.

[29] Johnston, R.J. (1978). Paradigms and revolution or evolution? Observations on human geography since the Second World War. Progress in Human Geography 2, 189-206.

[30] Jones, M. (1991). The elusive reality of landscape: concepts and approaches in landscape research. Norsk Geografisk Tidsskrift 45 (4), 229-244.

[31] Jones, M. (1993). Landscape as a resource and the problem of landscape values. In: Rusten, C. \& Woien, H. (eds.) The Politics of Environmental Conservation (pp. 19-33)). Proceedings from a workshop in Trondheim March 26, 1993. Trondheim: University of Trondheim.

[32] Jones, M. (2003). The concept of cultural landscape: discourse and narratives. In: Palang, $\mathrm{H}$. \& Fry, G. (eds.) Landscape Interfaces: Cultural Heritage in Changing Landscapes. Series: Décamps, H., Tress, B. \& Tess, G. (eds.) Landscape Series, Volume I. (pp. 21-51). Dordrecht: Kluwer Academic Publishers,.

[33] Maandi, P. (2009). The silent articulation of private land rights in Soviet Estonia: a geographical perspective. Geoforum 40, 454-464.

[34] Mander, Ü. \& Palang, H. (1994). Changes of landscape structure in Estonia during the Soviet period. GeoJournal 33 (1), 45-54.

[35] Olwig, K.R. 1996: Recovering the substantive nature of landscape. Annals of the Association of American Geographers 86 (4), 630-653.

[36] Olwig, K.R. (2002). Landscape, Nature and the Body Politic: from Britain's Renaissance to 
America's New World. Madison: University of Wisconsin Press.

[37] Palang, H. \& Fry, G. (2003). Landscape interfaces. In: Palang, H. \& Fry, G. (eds.) Landscape Interfaces: Cultural Heritage in Changing Landscapes (pp. 1-13). Series: Décamps, H., Tress, B. \& Tess, G. (eds.) Landscape Series Volume I. Dordrecht: Kluwer Academic Publishers.

[38] Palang, H., Helmfrid, S., Antrop, M., \& Alumäe, H. (2005). Rural landscapes: past processes and future strategies. Landscape and Urban Planning 70 (1-2), 3-8.

[39] Palang, H., Kaur, E., Alumäe, H. \& Jürimäe, K. (1999). Conflicts between landscape values as driving force for landscape management. Norsk Geografisk Tidsskrift 53 (2), 153-159.

[40] Palang, H., Mander, Ü. \& Luud, A. (1998). Landscape diversity dynamics in Estonia. Landscape and Urban Planning 41, 163-169.

[41] Palang, H. \& Printsmann, A. (2010). From totalitarian to democratic landscapes: the transition in Estonia. In: Primdahl, J. \& Swaffield, S. (eds.) Globalisation and Agricultural Landscapes: Change Patterns and Policy Trends in Developed Countries (pp. 169-184). Cambridge: Cambridge University Press.

[42] Palang, H., Printsmann, A., Konkoly Gyuró, É., Urbanc, M., Skowronek, E. \& Woloszyn, W. (2006). The forgotten rural landscapes of Central and Eastern Europe. Landscape Ecology 21 (3), 347-357.

[43] Peterson, U. \& Aunap, R. (1998). Changes in agricultural land use in Estonia in the 1990s detected with multitemporal Landsat MSS imagery. Landscape and Urban Planning 41, 193201.

[44] Pred, A. (1977). The choreography of existence: comments on Hägerstrand's time-geography and its usefulness. Economic Geography 53 (2), 207-221.

[45] Printsmann, A., Kõivupuu, M. \& Palang, H. (2010). The dual character of landscape in the Lahemaa national park, Estonia. In: Roca, Z., Claval P. \& Agnew J. (eds.) Landscapes, Identities and Development. Farnham: Ashgate Publishing, in press.

[46] Rausing, S. (2004). History, Memory and Identity in Post-Soviet Estonia. The End of a Collective Farm. Oxford: Oxford University Press.

[47] Roberts, N. et al. (2009). Obituary. Professor Mark Blacksell. Geographical Journal 174 (2), 179-181.

[48] Roe, M. (ed.) (2007). Special issue Regional Perspective: Transitional Landscapes in Eastern Asia. Landscape Research 32 (2), 111 -115

[49] Said, E. (1978). Orientalism. New York: Pantheon.

[50] Sauer, C.O. (1925). The morphology of landscape. University of California Publications in Geography 2 (2), 19-54.

[51] Schwartz, H. (2004). Down the wrong path: path dependence, increasing returns, and historical institutionalism. Unpublished manuscript http://people.virginia.edu/ hms2f/Path.pdf 25.05.2007.

[52] Sewell, W.H. (1996a). Historical events as transformations of structures: inventing revolution at the Bastille. Theory and Society 25 (6), 841-881.

[53] Sewell, W.H. (1996b). Three temporalities: toward an eventful sociology. In: McDonald, T.J. (ed.) The Historic Turn in the Human Sciences (pp. 245-280). Ann Arbor: University of Michigan Press.

[54] Sheppard, E. \& Nagar, R. (2004). From East-West to North-South. Antipode 36 (4), 557-563. DOI: 10.1111/j.1467-8330.2004.00433.x. 
[55] Skowronek, E., Krukowska, R., Swieca, A. \& Tucki, A. (2005). The evolution of rural landscapes in mid-eastern Poland as exemplified by selected villages. Landscape and Urban Planning 70, 45-56. DOI: 10.1016/j.landurbplan.2003.10.004.

[56] Skowronek, E., Woloszyn, W., Spek T. \& Born, K.M. (eds.) (2006). Cultural Landscapes of the Lublin Upland and Roztocze. Lublin.

[57] Smurr, R.W. (2008). Lahemaa: the paradox of the USSR's first national park. Nationalities Papers 36 (3), 399-423.

[58] Unwin, T. (1997). Agricultural restructuring and integrated rural development in Estonia. Journal of Rural Studies 13 (1), 93-112.

[59] Vervloet, J.A.J. (1984). Inleiding tot de historische geografie van de Nederlandse cultuurlandschappen. Wageningen: Pudoc.

[60] Vos, W. \& Meekes, H. (1999). Trends in European cultural landscape development: perspectives for a sustainable future. Landscape and Urban Planning 46(1-3), 3-14. Doi:10.1016/S0169-2046(99)00043-2.

[61] Vuorela, N., Alho, P. \& Kalliola, R. (2002). Systematic assessment of maps as source information in landscape-change research. Landscape Research 27 (2), 141-166.

[62] Widgren, M. (2004). Can landscapes be read? In: Palang, H., Sooväli, H. Antrop, M. \& Setten, G. (eds.) European Rural Landscapes: Persistence and Change in a Globalising Environment (pp. 455-465). Dordrecht: Kluwer Academic Publishers.

[63] Young, C. \& Light, D. (2001). Place, national identity and post-socialist transformations: an introduction. Political Geography 20(8), 941-955. Doi:10.1016/S0962-6298(01)00039-7. 